\title{
Serum progesterone concentrations in cows receiving embryo transfers
}

\author{
J. F. Hasler, R. A. Bowen, L. D. Nelson \\ and G. E. Seidel, Jr \\ Animal Reproduction Laboratory, Colorado State University, Fort Collins, Colorado 80523, \\ U.S.A.
}

\begin{abstract}
Summary. Progesterone concentrations in systemic blood were determined by radioimmunoassay in crossbred cattle used as recipients in an embryo transfer programme. An embryo was transferred surgically to the uterine horn of 528 females which were in oestrus within one half-day of the donor. Jugular blood was obtained at the time embryos were transferred (3-7 days after oestrus) and again from most females between Days 9 and 14. Pregnancy was determined by rectal palpation 4565 days after oestrus. There were no significant differences between serum progesterone levels of females which remained pregnant and those which did not. Out of 177 pregnant recipients, none had serum progesterone levels $<0.5 \mathrm{ng} / \mathrm{ml}$ on Days 10,11 , or 12 but in 8 , values were $<1.0 \mathrm{ng} / \mathrm{ml}$. Blood samples were also taken on Days 20,21 , or 22 from 113 of these recipients. The mean \pm s.e.m. concentration of progesterone in the pregnant females $(5.14 \pm 0.34 \mathrm{ng} / \mathrm{ml})$ was significantly higher $(P<0.001)$ than in the non-pregnant females $(1.17 \pm 0.25 \mathrm{ng} / \mathrm{ml})$. The correlation coefficients between progesterone levels on Days 3, 4, 5 or 6 and 10-12 ranged from 0.18 to 0.37 (all $P<0.02$ ). Progesterone levels were not related to length of the previous cycle, the time of day an animal was first noticed in oestrus or the side of the corpus luteum. However, cows with a short oestrus had higher progesterone levels on Days 3-7 $(P<0.01)$ than those in oestrus for a longer time.
\end{abstract}

\section{Introduction}

A number of investigators, including Shemesh, Ayalon \& Lindner (1968), Pope, Gupta \& Munro (1969), Henricks, Dickey \& Niswender (1970), Wettemann \& Hafs (1973), Erb, Garverick, Randel, Brown \& Callahan (1976) and Holness, Ellison \& Wilkins (1977) have reported systemic levels of progesterone during early pregnancy in the cow. These reports are about evenly divided on whether pregnant cows have higher levels of progesterone in blood than do non-pregnant cows 6-14 days after insemination. In the present study, progesterone concentrations in recipients in an embryo transfer programme were investigated in an attempt to resolve these conflicting data. In addition, the relationship between a number of physiological characteristics and progesterone levels was studied to determine if potential recipients could be screened to increase pregnancy rates from embryo transfer.

\section{Materials and Methods}

Animals. A total of 528 females, primarily Angus-Hereford crosses, were used. Most were 15-24 months of age but some older cows (up to 10 years old) were included. The daily ration 
was $15 \mathrm{~kg}$ corn silage and $2 \mathrm{~kg}$ alfalfa hay per head before surgery and $1 \mathrm{~kg}$ grain and alfalfa hay ad libitum after surgery. All animals were checked visually twice a day for behavioural oestrus approximately between $06: 30$ and $07: 30 \mathrm{~h}$ and $16: 30$ and 18:00 h, depending on length of daylight. Recipients had previous oestrous cycles of normal length (17-24 days) or, in a few cases, twice normal length (35-47 days). The day on which a female was first noticed in standing oestrus was considered Day 0 . The data reported in this study were collected over a period of approximately 1 year.

Embryo transfer. Embryos were recovered surgically from donor cows induced to superovulate as described by Elsden, Nelson \& Seidel (1978), and transferred surgically to recipients which were in natural oestrus within one half-day of the donor. Feed was withheld from donors and recipients for $24 \mathrm{~h}$ before surgery. Anaesthesia was induced with an intravenous injection of thiamylal (Surital: Parke-Davis, Denver, Colorado) or thiopental sodium (Pentothal: Abbott, North Chicago, Illinois) and maintained during surgery with halothane (Fluothane: Ayerst, New York, New York). Embryos were examined microscopically and cultured in HEPES-buffered (25 mM) Tissue Culture Medium 199 (GIBCO, Grand Island, New York) with 5\% heat-treated steer serum or in modified Ham's F-10 medium (Naglee, Maurer \& Foote, 1969) for up to $12 \mathrm{~h}$ at $37^{\circ} \mathrm{C}$ until transfer to a recipient. Embryos were transferred via a mid-line incision to the uterine horn ipsilateral to the corpus luteum. Animals were used as recipients only if a corpus luteum could be found. In about $10 \%$ of the recipients one of the following occurred: (1) the transfer did not proceed normally, resulting in some doubt that the transfer was made (only in a few cases); (2) the embryo was either morphologically abnormal or retarded in its stage of development (Elsden et al., 1978); or (3) one embryo was transferred to each uterine horn (only a few cases). Since treatment differences were virtually identical whether data from these categories were included or excluded, these categories have been included in the analyses presented because they are present in commercial embryo transfer situations.

Following surgery all recipients were checked twice daily for behavioural oestrus and pregnancy was diagnosed by rectal palpation $45-65$ days after surgery. Three recipients were known to have aborted and were not included in the analyses.

Blood collection. Blood $(15 \mathrm{ml})$ was collected from each recipient by jugular puncture before embryo transfer on the day of surgery (3-7 days after oestrus) usually within 1 min after induction of anaesthesia. A second sample was taken from most recipients between Days 9 and 14 and a third sample was taken from some recipients on Day 20, 21, or 22. Blood was allowed to clot at room temperature and then centrifuged. Serum was stored at $-20^{\circ} \mathrm{C}$ until assayed.

Assay for progesterone. A double-antibody radioimmunoassay procedure was used as described and validated by Niswender (1973). For each sample, $0.5 \mathrm{ml}$ serum was extracted twice with $5 \mathrm{ml}$ petroleum ether, the extract dried under nitrogen gas, reconstituted in $1.0 \mathrm{ml}$ buffer solution and assayed in duplicate $200 \mu \mathrm{l}$ aliquots. Values were corrected for extraction losses in each sample by adding trace quantities of tritiated progesterone. The average efficiency of extraction was $83 \%$. The average standard error of the 3 buffer control tubes within each of the 12 assays was equivalent to $0.7 \mathrm{pg}$ progesterone, which is a measure of the limit of detection. The means \pm s.d. of water and solvent blanks were $40 \pm 38$ and $36 \pm 35 \mathrm{pg} / \mathrm{ml}$. A standard serum sample $(2.02 \mathrm{ng}$ progesterone $/ \mathrm{ml})$ was always assayed in duplicate, from which intra- and inter-assay coefficients of variation of 13.6 and $18.2 \%$ were calculated.

Data analysis. The relationships between the following characteristics and progesterone levels on Days 3-7 and 9-14 were evaluated by analysis of variance: (1) previous oestrous cycle lengths, which were classified as short (17-19 days), medium (19.5-21.5 days) or long (22-24 days); (2) length of oestrus, which was classified as short (noticed in oestrus only at the morning or afternoon detection period) or long (noticed in oestrus at 2 or 3 consecutive detection periods); (3) the time of day when first noticed in oestrus; (4) the side of ovulation, left or right; and (5) whether the recipient maintained the pregnancy or was non-pregnant at palpation.

In order to make the analysis of these data more practical, the days of the oestrous cycle on 
which samples were collected were used as a covariate instead of a factor. The statistical validity of this approach was checked by polynomial regression. Simple linear regression was as good as more complicated models for describing increasing progesterone concentrations in blood between Days 3 and 14 of the oestrous cycle; furthermore, the equations for pregnant and nonpregnant cattle were virtually identical. The equation with the 878 progesterone samples for pregnant and non-pregnant recipients was: progesterone level $(\mathrm{ng} / \mathrm{ml}$ serum $)=-0.73+0.558$ (day of cycle), $r=0.62(P<0.001)$.

Separate analyses of variance were calculated for data from Days 3-7 and 9-14 of the cycle. Main effects and two-way interactions were calculated by least squares analysis (Harvey, 1960). Preliminary analyses showed that there were no significant three-way interactions so these were not included in the model. While variances of progesterone levels tended to increase with the mean, no transformations were used since analysis of data transformed by taking the logarithm or square root of the data was virtually identical to that of untransformed data.

\section{Results}

As shown in Table 1, progesterone concentrations in recipients that remained pregnant were not significantly different $(P>0 \cdot 1)$ from those of recipients in which pregnancy was not maintained. Furthermore, the lowest levels of progesterone observed in females that remained pregnant were comparable to the lowest levels observed in those that did not remain pregnant. Conception resulted from transfer of embryos to recipients whose progesterone levels were as low as $0.06 \mathrm{ng} / \mathrm{ml}$ on Day 3, $0.28 \mathrm{ng} / \mathrm{ml}$ on Day $4,0.13 \mathrm{ng} / \mathrm{ml}$ on Day 5 and $0.20 \mathrm{ng} / \mathrm{ml}$ on Day 6. Seven non-pregnant and 8 pregnant animals had progesterone levels $<1.0 \mathrm{ng} / \mathrm{ml}$ serum on Days 10,11 or 12 . The lowest value in a pregnant female after Day 9 was 0.53 ng progesterone $/ \mathrm{ml}$ on Day 11 . Three non-pregnant females had progesterone levels $<0.50 \mathrm{ng} / \mathrm{ml}$; the lowest was $0.19 \mathrm{ng} / \mathrm{ml}$ on Day 12 . Progesterone concentrations $>11 \mathrm{ng} / \mathrm{ml}$ were found in 13 animals on Days 10-12 and 6 were pregnant. The highest progesterone concentration found was $21.4 \mathrm{ng} / \mathrm{ml}$ on Day 10.

Table 1. Least-squares means of progesterone concentrations $(\mathrm{ng} / \mathrm{ml})$ in blood serum of cows receiving embryo transfers (no. of recipients in parentheses)

\begin{tabular}{lcc}
\hline & $\begin{array}{c}\text { Before embryo transfer } \\
\text { (Days 3-7) }\end{array}$ & $\begin{array}{c}\text { After embryo transfer } \\
\text { (Days 9-14) }\end{array}$ \\
\hline Pregnancy not maintained & $1.74(253)$ & $5.43(167)$ \\
Remained pregnant & $1.93(263)$ & $5 \cdot 18(195)$ \\
CL in left ovary & $1.79(218)$ & $5.42(155)$ \\
CL in right ovary & $1.88(298)$ & $5 \cdot 19(207)$ \\
First in oestrus morning & $1.83(302)$ & $5.16(212)$ \\
First in oestrus afternoon & $1.84(214)$ & $5 \cdot 45(150)$ \\
Short oestrus & $2.10(224)^{* *}$ & $5.49(152)$ \\
Long oestrus & $1.57(292)$ & $5 \cdot 12(210)$ \\
17-19-day cycles & $2.05(125)$ & $5.31(83)$ \\
19.5-21.5-day cycles & $1.81(319)$ & $5.53(230)$ \\
22-24-day cycles & $1.65(72)$ & $5.07(49)$ \\
Linear regression/day of cycle & $0.63(516)^{* *}$ & $0.02(362)$ \\
Error degrees of freedom & 494 & 340 \\
Error mean squares & 1.88 & 9.67 \\
\hline \multicolumn{2}{l}{}
\end{tabular}


Neither previous oestrous cycle length nor the time an animal was first noticed in oestrus was related to progesterone levels and there were no significant interactions $(P>0.05)$. However, recipients with a short oestrus had higher progesterone levels $(P<0.01)$ than those with a long oestrus in samples taken between Days 3 and 7 but not later (Table 1). The regression coefficient of the covariate was significant for samples taken before embryo transfer $(P<0.01)$ but not for later samples (Table 1), because progesterone concentrations in blood reached a plateau by Day 10 (Table 2).

Table 2. Mean \pm s.d. progesterone concentrations $(\mathrm{ng} / \mathrm{ml})$ in blood serum of cows receiving embryo transfers (no. of cows in parentheses)

\begin{tabular}{clll}
\hline $\begin{array}{c}\text { Days after } \\
\text { oestrus }\end{array}$ & Pregnant recipients & $\begin{array}{c}\text { Non-pregnant recipients } \\
\text { showing normal return } \\
\text { to oestrus* }\end{array}$ & $\begin{array}{c}\text { Non-pregnant recipients } \\
\text { showing abnormal return } \\
\text { to oestrus } \dagger\end{array}$ \\
\hline $\begin{array}{c}\text { Before transfer } \\
2.5-3\end{array}$ & $0.85 \pm 0.39(5)$ & $0.99 \pm 0.64(16)$ & $1.04 \pm 0.95(7)$ \\
$3.5-4$ & $1.26 \pm 0.78(66)$ & $1.18 \pm 0.90(47)$ & $1.30 \pm 0.79(22)$ \\
$4.5-5$ & $1.84 \pm 1.32(124)$ & $1.59 \pm 0.96(86)$ & $1.67 \pm 0.89(22)$ \\
$5.5-6$ & $2.85 \pm 2.36(63)$ & $2.81 \pm 1.90(30)$ & $2.90 \pm 1.89(16)$ \\
$6.5-7$ & $3.86 \pm 2.68(5)$ & $1.48 \pm 0.44(5)$ & \\
7.5 & & $3.74(1)$ & $2.50(1)$ \\
After transfer & & & \\
$8.5-9$ & $4.28 \pm 1.76(8)$ & $2.94 \pm 1.76(4)$ & $1.80,5.54(2)$ \\
$9.5-10$ & $6.38 \pm 3.37(58)$ & $6.27 \pm 4.72(33)$ & $3.52 \pm 2.85(16)$ \\
$10.5-11$ & $4.84 \pm 2.67(77)$ & $5.39 \pm 2.53(44)$ & $5.59 \pm 2.66(8)$ \\
$11.5-12$ & $5.30 \pm 2.11(42)$ & $5.20 \pm 3.52(33)$ & $5.40 \pm 2.94(10)$ \\
$12.5-13$ & $4.85 \pm 2.65(9)$ & $6.97 \pm 3.76(10)$ & $3.82 \pm 2.16(3)$ \\
$13.5-14$ & $3.70(1)$ & $4.68 \pm 8.42(3)$ & $7.70(1)$ \\
\hline
\end{tabular}

* $17-24$ or $35-47$ days after pre-transfer oestrus.

$+10-16 \cdot 5,24 \cdot 5-34 \cdot 5$ or $>47$ days after pre-transfer oestrus.

Progesterone concentrations among the three groups analysed in Table 2 were similar; the standard deviations increased as the means increased. The pregnancy rates were 18, 49, 53 and $58 \%$ pregnant for embryo transfers on Days 3, 4, 5 and 6 (Table 2). This trend is very similar to that noted by Newcomb \& Rowson (1975).

Serum progesterone levels at 20,21 or 22 days after oestrus were $5 \cdot 14 \pm 0 \cdot 34$ (s.e.m.) $\mathrm{ng} / \mathrm{ml}$ in 52 pregnant females and $1.17 \pm 0.25 \mathrm{ng} / \mathrm{ml}$ in 61 non-pregnant females $(P<0.001)$. If a value of $2 \mathrm{ng}$ progesterone $/ \mathrm{ml}$ serum is used to discriminate pregnant from non-pregnant recipients, $92 \%$ of these 113 recipients would be classified correctly: 3 pregnant females had progesterone levels $<2 \mathrm{ng} / \mathrm{ml}$ on Days $20-22$, the lowest value being $0.97 \mathrm{ng} / \mathrm{ml}$ on Day 20 , and 6 non-pregnant recipients had progesterone levels $>2 \mathrm{ng} / \mathrm{ml}$. Observations of behavioural oestrus in these 6 females indicated that they all exhibited a long oestrous cycle ( $>25$ days) following embryo transfer. If the progesterone levels of all 7 females in the non-pregnant group with cycles longer than 25 days are eliminated from analysis, the progesterone value for non-pregnant females is decreased to $0.59 \pm 0.06 \mathrm{ng} / \mathrm{ml}$.

There were significant correlations between progesterone levels on Days 3, 4, 5 and 6 and those on Days 10-12 for the non-pregnant and pregnant females considered as a group (Table 3). However, the correlation coefficients for all four comparisons accounted for only $3-14 \%$ of the observed variation.

Data from 8 females ( $1.5 \%$ of total) without an obvious corpus luteum at the time of surgery were not included. A total of 9 recipients had a corpus luteum that seemed small for the stage of the cycle, appeared cyanotic, or possessed either no crown or a small crown. Serum progesterone concentrations in these females $(2.58 \pm 0.51 \mathrm{ng} / \mathrm{ml})$ were comparable to those in females (Table 1) that possessed corpora lutea of normal appearance on Days 3-7. 
Table 3. Correlations of progesterone levels between Days $3,4,5$ or 6 and Days $10-12$

\begin{tabular}{cccc}
\hline Days & $\begin{array}{c}\text { No. of } \\
\text { cows }\end{array}$ & $\begin{array}{c}\text { Correlation } \\
\text { coefficient }\end{array}$ & $P$ \\
\hline $3-3.5$ & 39 & 0.37 & $<0.02$ \\
$4-4.5$ & 137 & 0.28 & $<0.001$ \\
$5-5.5$ & 177 & 0.18 & $<0.01$ \\
$6-6.5$ & 59 & 0.31 & $<0.01$ \\
\hline
\end{tabular}

\section{Discussion}

At the time of embryo transfer, there was no significant difference in blood serum progesterone levels between recipients which remained pregnant and those which did not. Since progesterone levels fluctuate considerably over short periods in the same animal (Peterson, Fairclough, Payne \& Smith, 1975), it is possible that several samples taken at hourly intervals would be more diagnostic. The only other known study relating progesterone levels in recipients and pregnancy rates with bovine embryo transfer is that of Hahn et al. (1977), who measured milk progesterone in 8 pregnant and 8 non-pregnant recipients on Days 1,4 , and 7 . Their findings were similar to ours, although there was a suggestion of more variation with the non-pregnant recipients. One other related study by Henricks, Lamond, Hill \& Dickey (1971) presented data suggesting that progesterone levels 1 day before oestrus were inversely related to the degree of ovum cleavage observed 3 days after oestrus. Studies with steroid-treated, ovariectomized sheep (Moore, 1975) and with asynchronous transfer (Lawson, 1977) show that subtle differences in the hormonal milieu can have profound effects on embryonic development.

The progesterone levels in pregnant and non-pregnant cows on Days 9-14 closely resemble those reported by Shemesh et al. (1968) and Pope et al. (1969) in Friesian cows and Robertson \& Sarda (1971) in Holsteins. Henricks et al. (1970), however, reported that pregnant beef cows exhibited significantly higher progesterone levels on Days 10-14 than did non-pregnant cows; values were similar on Day 16 and then diverged again from Day 17. Progesterone levels have been reported to be higher in pregnant cows as early as Day 6 (Henricks et al., 1971; Erb et al., 1976) and Day 13 after oestrus (Holness et al., 1977). The values given by Henricks et al. (1971) for pregnant cows were substantially higher than those in the pregnant heifers at Days 10-12 in the present study, and those reported by Erb et al. (1976) for non-pregnant animals were substantially lower than those in the present study. All of the aforementioned studies had small sample sizes, and other factors, e.g. dietary regimen (Erb et al., 1976), may also have influenced the results. Insemination at oestrus (Henricks et al., 1970, 1971) could have led to possible 'feed-back' influences of the embryo (e.g. Haour \& Saxena, 1974) for a longer period before blood sampling.

Under the conditions of our experiment, it is clear that progesterone levels during Days 3-14 of the oestrous cycle are not related to pregnancy rates with embryo transfer. Similarly, a recent study by Bulman \& Lamming (1978) with inseminated cows showed no difference during this interval between pregnant and non-pregnant cows in progesterone concentrations in milk.

The higher incidence of ovulation from the right ovary than the left $(57.8$ versus $42.2 \%$, $n=516$ ) confirmed previous reports (Reece \& Turner, 1938) but this did not affect progesterone levels. The highly significant relationship between progesterone levels and length of oestrus was unexpected. It was probably due to earlier ovulation relative to time of blood sampling in the group noticed in oestrus only at one observation period. Cows that first came into standing oestrus just after an observation period were less likely to remain in oestrus for 2 consecutive checks than cows that came in just before an observation period. If there was an average difference between these two groups of $12 \mathrm{~h}$ from when oestrus was first noticed to ovulation, one 
would expect $0.31 \mathrm{ng}$ progesterone/ $\mathrm{ml}$ difference, which is half the regression coefficient from Table 1. This would explain much of the difference.

Our data on the use of progesterone levels on Days 20-22 for pregnancy diagnosis are in agreement with the findings of a number of authors, including Pope et al. (1969), Shemesh et al. (1973), Wishart, Head \& Horth (1975) and Seguin, Stellflug, Kiser \& Oxender (1975). A progesterone level of $2 \mathrm{ng} / \mathrm{ml}$ serum was suitable for differentiating between pregnant and nonpregnant cows. Had the $1 \mathrm{ng} / \mathrm{ml}$ level suggested by Robertson \& Sarda (1971) been used in the present study, 51/52 animals would have been correctly diagnosed as pregnant. However, 13/61 non-pregnant females would have been diagnosed incorrectly. The most suitable progesterone level for use in pregnancy diagnosis will probably vary because of variation in assays among laboratories and the type of management programme. If non-pregnant animals are to be sold, it would probably be preferable to diagnose non-pregnant cattle as pregnant rather than the converse. For example, a cut-off point of $3 \mathrm{ng} / \mathrm{ml}$ as suggested by Wishart et al. (1975) might result in the sale of a large number of pregnant cows. In the present study $12 / 52$ pregnant recipients had levels $<3 \mathrm{ng} / \mathrm{ml}$ on Days 20,21 or 22 .

This work was partly supported by Regional Project W-112, Reproductive Performance in Beef Cattle and Sheep and a grant from Select Sires, Inc., Plains City, Ohio. We thank G. D. Niswender for the reagents and facilities for radioimmunoassay and J. Bowen, R. Carter, L. Case, N. Homan, N. Okun, L. Roesener, S. Seidel, E. Sun and P. Sluss for technical assistance.

\section{References}

Bulman, D.C. \& Lamming, G.E. (1978) Milk progesterone levels in relation to conception, repeat breeding and factors influencing acyclicity in dairy cows. $J$. Reprod. Fert. 54, 447-458.

Elsden, R.P., Nelson, L.D. \& Seidel, G.E., Jr (1978) Superovulating cows with follicle stimulating hormone and pregnant mare's serum gonadotrophin. Theriogenology 9, 17-26.

Erb, R.E., Garverick, H.A., Randel, R.D., Brown, B.L. \& Callahan, C.J. (1976) Profiles of reproductive hormones associated with fertile and nonfertile inseminations of dairy cows. Theriogenology 5, 227242.

Hahn, J., Hahn, R., Baumgärtner, G., Lotthammer, K.-H., Lorrmann, W., Schneider, U., Traub, J. \& Zoder, H.F. (1977) Untersuchungen zur Verbesserung der Auswahl von Spender-und Empfängertieren im Rahmen der Eiübertragung beim Rind. Zuchthygiene 12, $68-76$.

Haour, F. \& Saxena, B.B. (1974) Detection of a gonadotropin in rabbit blastocyst before implantation. Science, N.Y. 185, 444-445.

Harvey, W.R. (1960) Least-squares analysis of data with unequal subclass frequencies. USDA, Agricultural Research Service. USDA Pub., ARS 20-8.

Henricks, D.M., Dickey, J.F. \& Niswender, G.D. (1970) Serum luteinizing hormone and plasma progesterone levels during the estrous cycle and early pregnancy in cows. Biol. Reprod. 2, 346-351.

Henricks, D.M., Lamond, D.R., Hill, J.R. \& Dickey, J.F. (1971) Plasma progesterone concentrations before mating and in early pregnancy in the beef heifer. J. Anim. Sci. 33, 450-454.

Holness, D.H., Ellison, J.A. \& Wilkins, L.M. (1977)
Conception of beef cows in relation to the concentration of progesterone in peripheral blood. Rhod. $J$. Agric. Res. 15, 3-9.

Lawson, R.A.S. (1977) Research applications of embryo transfer in sheep and goats. In Embryo Transfer in Farm Animals, pp. 72-78. Ed. K. J. Betteridge. Canada Dept. Agric., Ottawa.

Moore, N.W. (1975) Progesterone requirements for the maintenance of pregnancy in the ovariectomized ewe. J. Reprod. Fert. 43, 386-387.

Naglee, D.L., Maurer, R.R. \& Foote, R.H. (1969) Effect of osmolarity on in-vitro development of rabbit embryos in a chemically defined medium. Expl Cell Res. 58, 331-333.

Newcomb, R. \& Rowson, L.E.A. (1975) Conception rate after uterine transfer of cow eggs in relation to synchronization of oestrus and age of eggs. $J$. Reprod. Fert. 43, 539-541.

Niswender, G.D. (1973) Influence of the site of conjugation on the specificity of antibodies to progesterone. Steroids 22, 413-424.

Peterson, A.J., Fairclough, R.J., Payne, E. \& Smith, J.F. (1975) Hormonal changes around bovine luteolysis. Prostaglandins 10, 675-684.

Pope, G.S., Gupta, S.K. \& Munro, I.B. (1969) Progesterone levels in the systemic plasma of pregnant, cycling and ovariectomized cows. J. Reprod. Fert. 20, 369-381.

Reece, R.P. \& Turner, C.W. (1938) The functional activity of the right and left bovine ovary. J. Dairy Sci. 21, 37-39.

Robertson, H.A. \& Sarda, I.R. (1971) A very early pregnancy test for mammals: its application to the cow, ewe and sow. J. Endocr. 49, 407-419. 
Seguin, B.E., Stellfiug, J.N., Kiser, T.E. Oxender, W.D. (1975) Pregnancy diagnosis by progesterone in beef cattle. J. Anim. Sci. 41, 378, Abstr.

Shemesh, M., Ayalon, N. \& Lindner, H.R. (1968) Early effect of conceptus on plasma progesterone level in the cow. J. Reprod. Fert. 15, 161-164.

Shemesh, M., Ayalon, N. \& Lindner, H.R. (1973) Early pregnancy diagnosis based upon plasma progesterone levels in the cow and ewe. J. Anim. Sci. 36, 726-729.

Wettemann, R.P. \& Hafs, H.D. (1973) LH, prolactin, estradiol and progesterone in bovine blood serum during early pregnancy. J. Anim. Sci. 36, 51-56.

Wishart, D.F., Head, V.A. \& Horth, C.E. (1975) Early pregnancy diagnosis in cattle. Vet. Rec. 96, 34-38.

Received 6 March 1979 